\title{
Effect of Four Crude-Protein Concentrate Mixes upon Milk Production in Puerto Rico
}

\author{
J. A. Arroyo-Aguilu, L. Rivera-Brenes, and J. I. Cabrera
}

INTRODUCTION

The determination of the level of crude protein in concentrate mixes that should be fed to milking cows has been a topic under consideration for many years. High-protein concentrate mixes (20 and 24 percent) are fed commonly to milking cows in Puerto Rico. No research work has been conducted, however, to determine the best level of crude protein in concentrate rations to feed producing dairy cows under our conditions.

This paper presents results of an evaluation of tests involving four crudeprotein levels in concentrate mixes, in combination with cut forage, and their effects on dairy cows. This feeding method is representative of the one used in dairies of Puerto Rico when the tests were conducted. By the time the experiment was finished, however, many farms had changed to the grazing system.

\section{REVIEW OF LITERATURE}

Harrison and Savage (5) ${ }^{2}$ found that a 16-percent crude-protein concentrate, with timothy-clover hay and corn silage as roughages, furnishes as efficient and economic milk production as either a 20- or a 24-percent crudeprotein concentrate, when fed at a rate of 1 pound of concentrate for each 3.5 pounds of milk produced.

Moore (7) reported no differences in milk production between groups of cows fed grain mixtures containing three levels of crude protein (18.5 to 19.5 percent, 14.5 to 15.5 percent, and 10.0 to 11.0 percent) over two lactation periods.

Two trials with lactating dairy cows were conducted by Lassiter et al. (6). They observed that the requirements were not met with grain rations containing either 7.9- or 9.1-percent crude protein. The requirements were met, however, by concentrate rations containing either 10.3 or 11.9 percent of crude protein.

Bishop and Bath (E), in California, maintained equal milk production when using concentrate rations of 12- and 17-percent crude protein.

1 Assistant Nutritionist and Head, respectively, Animal Husbandry Department, Agricultural Experiment Station, Mayagüez Campus, University of Puerto Rico, Rio Piedras, P.R.; and former Associate Animal Husbandman in the Animal Husbandry Department.

Italic numbers in parentheses refer to Literature Cited, p. 81. 


\section{PROCEDURE}

Our experiment was started in September 1952 and completed in July 1959. A switchback or double-reversal experimental design (3) was used in this study. The four concentrates used (table 1) contained 12, 16, 20, and 24 percent of crude protein (table 2). Each experimental period consisted of three trial periods (table 3), with four or five cows in each period.

TABLE 1.-Comparative composition of four concentrate mixes of different crude-protein levels

\begin{tabular}{l|c|c|c|c}
\hline \multirow{2}{*}{ Ingredient } & \multicolumn{4}{|c|}{ Concentrate mix (protein level) } \\
\cline { 2 - 3 } & 12-percent & 16-percent & 20-percent & 24-percent \\
\hline & Percent & Percent & Percent & Percent \\
Brewers' dried grain & 6.7 & 14.0 & 6.7 & 4.9 \\
Corn gluten feed & 6.7 & 6.7 & 6.0 & 3.3 \\
Ground oats & 6.7 & 6.7 & 6.7 & 3.3 \\
Citrus pulp & 32.3 & 20.0 & 6.7 & 3.3 \\
Concentrate 32-percent (closed & 10.7 & 22.3 & 43.0 & 62.2 \\
formula) & & & & \\
Ground corn & 10.0 & 6.7 & 6.7 & 3.3 \\
Wheat bran & 10.0 & 6.7 & 7.3 & 3.3 \\
Minerals (1-percent minerals & 2.0 & 2.0 & 2.0 & 2.0 \\
$\quad$ and 1-percent salt) & 15.0 & 15.0 & 15.0 & 15.0 \\
Molasses & & &
\end{tabular}

TABLE 2.-Proximate analyses of four concentrate mixes (dry-matter basis) of different crude-protein levels

\begin{tabular}{c|c|c|c|c|c}
\hline $\begin{array}{c}\text { Crude-protein } \\
\text { concentrate level }\end{array}$ & $\begin{array}{c}\text { Crude } \\
\text { protein }\end{array}$ & $\begin{array}{c}\text { Crude } \\
\text { fiber }\end{array}$ & $\begin{array}{c}\text { Ether } \\
\text { extract }\end{array}$ & Ash & $\begin{array}{c}\text { Nitrogen-free } \\
\text { extract }\end{array}$ \\
\cline { 1 - 2 } \cline { 2 - 5 } Percent & Percent & Percent & Percent & Percent & Percent \\
12 & 12.61 & 7.77 & 2.47 & 8.28 & 64.98 \\
16 & 18.20 & 8.86 & 2.08 & 9.66 & 62.96 \\
20 & 22.73 & 7.80 & 2.11 & 12.71 & 50.76 \\
24 & 26.88 & 7.67 & 1.75 & 14.73 & 45.08 \\
\hline
\end{tabular}

Each trial period was conducted during the entire 305-day lactation period of the cows. The normal milk-production records of the cows that did not complete their lactation periods were corrected and adjusted to 305 days. The abnormal records were eliminated.

Cows started in this study on their first or second lactation periods and continued for two additional consecutive lactation periods. Five days after the cows freshened, they were incorporated into the experiment. Most of the animals were Holstein but a few were Brown-Swiss. 
Each cow was weighed at the beginning of each trial period and monthly thereafter. A uniform ratio of 1 pound of concentrate mix to every 2.5 pounds of milk produced, adjusted every 10 days, was fed to each animal throughout the experiment.

The cows were kept in stanchions all day for feeding and milking and released into an exercise lot in the evening. They were milked twice a day: about 7:00 a.m. in the morning and about 3:00 p.m. in the afternoon. The roughage, mostly Napier (Merker) grass fed ad libitum, varied in nutritive value from good to poor due to seasonal and annual differences. All animals consumed similar roughage.

TABLE 3.-Double-reversal protein-level feeding schedules used in 160 lactation periods

\begin{tabular}{c|c|c}
\hline \multicolumn{2}{c}{ Protein-feeding experimental period } \\
\hline First trial period & Second trial period & Third trial period \\
\hline Percent & Percent & Percent \\
$12(5)^{1}$ & $16(5)$ & $12(5)$ \\
$12(4)$ & $20(4)$ & $12(4)$ \\
$12(4)$ & $24(4)$ & $12(4)$ \\
$16(5)$ & $12(5)$ & $16(5)$ \\
$16(4)$ & $20(4)$ & $16(3)$ \\
$16(5)$ & $24(5)$ & $16(5)$ \\
$20(5)$ & $12(5)$ & $20(5)$ \\
$20(4)$ & $16(4)$ & $20(4)$ \\
$20(5)$ & $24(5)$ & $20(5)$ \\
$24(4)$ & $12(4)$ & $24(3)$ \\
$24(4)$ & $16(4)$ & $24(4)$ \\
$24(5)$ & $20(5)$ & $24(5)$ \\
\hline
\end{tabular}

1 Numbers in parentheses refer to the number of cows per treatment.

All the milk produced, the concentrate mix fed, and the roughage (soilage) consumed were reported. The butterfat percentage in milk samples was determined by means of the Babcock test. Chemical determinations were made periodically of the concentrate mixes according to A.O.A.C. methods ( 1 ).

At the end of this study, 160 lactation records were completed. The milk production per cow, the sole criterion for evaluation, was converted to 4 percent fat-corrected milk (F.C.M.) by using Gaines formula (4), i.e., 4-percent F.C.M. $=0.4 M$ (milk yield) $+15 F$ (fat yield).

The data obtained in this study were analysed statistically by means of variance analyses whereby the 12-percent crude-protein level was compared to 16-, 20-, and 24-percent crude-protein levels; 16-percent to the 20- and 24-percent levels; and 20-percent to the 24-percent level, respectively. 


\section{RESULTS, DISCUSSION, AND CONCLUSIONS}

Average total concentrate and roughage (soilage) intake, milk production and live weight per lactation period are presented in table 4. No statistical significance (table 5) in 4-percent F.C.M. was found between concentrate levels. The statistical analysis demonstrated that all four treatments were equally good, and no treatment was better than the other. It was observed that milking cows do as well with the lowest as with the highest crudeprotein concentrate level, and probably will be more significant in cows kept under a grazing system. These results agree with those obtained by Harrison and Savage (5) and by Bishop and Bath (2), already cited.

TABLE 4.-Average total concentrate and roughage intake, total milk output, and animal weight per lactation period, 160 cow-lactations

\begin{tabular}{c|c|c|c|c}
\hline $\begin{array}{c}\text { Crude-protein } \\
\text { concentrate level }\end{array}$ & Concentrate & Roughage & F.C.M. M. output & $\begin{array}{c}\text { Anima } \\
\text { weight }\end{array}$ \\
\hline Percent & $K_{g .}$ & $K_{g}$. & $K_{g .}$ & $K_{g .}$ \\
12 & 1056 & 9017 & 2175 & 405 \\
16 & 1135 & 8716 & 2275 & 422 \\
20 & 1039 & 8546 & 2080 & 407 \\
24 & 1125 & 8188 & 2261 & 407 \\
\hline
\end{tabular}

Table 5.-Statistical comparisons between crude-protein concentrate levels, 160 cowlactations

\begin{tabular}{c|c|c|c}
\hline Crude-protein level & 16 percent & 20 percent & 24 percent \\
\hline 12 percent & +0.1303 & +0.8976 & +0.3305 \\
16 percent & & +0.7689 & +0.2168 \\
20 percent & & +0.5747 \\
\hline
\end{tabular}

Concentrate consumption and milk production (table 4) increased at the 16-percent crude-protein level, later decreased somewhat, and then increased at the 24-percent level.

Roughage consumption (table 4) followed a different trend. It decreased with increasing crude-protein concentrate levels.

Animal weight (table 4) increased at the 16-percent crude-protein concentrate level, then decreased and remained constant at 20- and 24-percent concentrate levels.

Observations on 160 cow-lactations through 8 years indicate that all four crude-protein level treatments were equally good. It can be concluded that crude-protein percentages in concentrates as low as 12 percent and 16 percent can be fed dairy cows. This should result in savings in feed cost. 
At present almost all dairies in Puerto Rico are feeding 20-percent protein feeds.

\section{SUMMARY}

A study was undertaken to compare the effect of four levels of crudeprotein in concentrate mixes on the milk production of cows fed cut forage as green-chop in Puerto Rico. The double-reversal experimental design was used in the study. The four levels of crude-protein used were: 12-, 16-, 20-, and 24-percent. Each of 54 milking cows were used for three consecutive lactation periods. Each animal received a uniform ratio of 1 pound of concentrate mix to every 2.5 pounds of milk, and the proportion of concentrate fed to milk produced was adjusted every 10 days. Milk production expressed as 4-percent fat-corrected milk was the only criterion for evaluation.

Napier (Merker) grass, the roughage mostly consumed, varied in nutritive value from good to fair to poor, due to seasonal and annual differences. All animals in this study consumed Merker grass ad libitum.

Milk production, concentrate, and roughage consumption data were recorded. Animal weights were recorded at the beginning of each period and then monthly thereafter.

No statistical differences were observed in milk production between the four concentrate levels. It can be concluded that all four treatments were equally good. If concentrate feeds with lower crude-protein content can be purchased at less cost, dairymen will reduce their production costs by feeding them.

\section{RESUMEN}

Se hizo un estudio para comparar el efecto del suministro de proteína cruda, a cuatro niveles, a saber, $12,16,20$ y 24 por ciento, en diferentes mezclas de alimentos concentrados sobre la producción de leche de cada una de 54 vacas lecheras durante 3 periodos consecutivos de lactancia.

A cada vaca se le suministró 1 libra de alimento concentrado por cada 2.5 libras de leche producidas y cada 10 días se ajustó porporcionalmente el suministro de concentrados a base de la cantidad de leche producida. La producción de leche expresada como leche corregida al 4 por ciento de grasa, se usó como único criterio para la evaluación de los tratamientos.

El forraje que más se utilizó fue la yerba Napier (Merker). Su valor nutritivo varió de bueno a poco alimenticio, debido a las diferencias entre las estaciones y entre los años. Todos los animales consumieron la yerba Merker a voluntad.

Se tabuló tanto la producción de leche como el consumo de alimento concentrado y de forraje. Las vacas se pesaron al comienzo de cada prueba y luego cada mes. 
No se observaron diferencias significativas en la producción de leche entre los cuatro niveles de proteína usados en los alimentos concentrados. Puede concluirse que las cuatro mezclas de alimentos concentrados ejercieron el mismo efecto sobre la producción de leche.

De poderse conseguir alimentos concentrados con niveles de proteína cruda más bajos y por ende más baratos, los ganaderos podrían adquirirlos y así bajar los costos de producción de la leche.

\section{LITERATURE CITED}

1. Association of Official Agricultural Chemists (A.O.A.C.), Official Methods of Analysis, 9th. ed., Washington, D. C., 1960.

2. Bishop, S. E. and Bath, D. L., Testing effects of low us. high-level protein concentrate mixes for dairy milk production, Calif. Agr. 20 (4): 4-5, 1966.

3. Brandt, A. E., Tests of Significance in Reversal or Switchback Trials, Res. Bull, 234, Iowa Agr. Expt. Sta., Ames, Iowa, 1938.

4. Gaines, W. L., The Energy Basis of Measuring Milk Yield in Dairy Cows, Bull. 308, Ill. Agr. Expt. Sta., Urbana, Mlinois, 1928.

5. Harrison, E. S., and Savage, E. S., The Effect of Different Planes of Protein Intake upon Milk Production, Bull. 540, Cornell Agr. Expt. Sta., Ithaca, N. Y., 1932.

6. Lassiter, C. A., Huffman, C. F., Duneson, C. W., and Ward, G. M., Effect of various protein levels on milk production, body weight changes and metabolism of lactating dairy cows, Mich. State Univ., Quart. Bull. 40 (1): 59-64, 1957.

7. Moore, L. A., Tomorrow's rations for dairy cows, Inf. Bull, 160 B., ARS USDA, 1954. 